\title{
Characterization of Climate Change Communication: Implication for Environmental Sustainability in Ogba, Egbema, Ndoni Local Government Area of River State, Nigeria

\section{| Peace Nwaerema ${ }^{1}$ | Nwokezi John Ikoro² |}

${ }^{1}$ Deparment of Geography,
Ibrahim Badamasi Babangida
University, Lapai, Nigeria
${ }^{2}$ Deparment of Mass
Communication, Captain
Elechi Amadi Polytechnic,
Rumuola, Port Harcourt,
Nigeria
${ }^{1}$ pnwaerema486@gmail.com
${ }^{2}$ john.nwokezi@portharcourtpoly.
edu.ng

\begin{abstract}
Communicating climate change occurrence in Ogba Egbema Ndoni Local Government Area of Rivers State was the key interest of this study due to the incessant environmental degradation caused by multinational oil and gas companies in the area. This study used multi-stage cluster sampling technique and administered four hundred (400) questionnaires in a study population of 445,760 persons determined by Taro Yamane statistical technique. The findings revealed that the stakeholders felt that climate change really occurred in the area but had not adequately adapted to the impact of climate change with $69.3 \%$ showing poor preparedness to climate change adaptation. The radio, television and town-hall meeting were the most effective media of climate change communication, but social media such as WhatsApp, Facebook, Twitter, Instagram, Telegram et cetera were poorly used to communicate climate change phenomenon. Thus, the indigenous town-crying communication medium showed 95\% response of disagreement of not being used to inform the stakeholders of climate change occurrence. However, $68 \%$ response revealed that the government was not concerned with climate change communication in the area, rather, Non-governmental Organizations (NGOs), Community Based Organizations (CBOs) and the host companies relatively showed concerned in communicating climate change occurrence to the stakeholders. The result indicated that the level of climate change occurrence did not statistically significantly relate with climate change communication in the area. Thus, it was recommended that community stakeholders should have access to weather information, agricultural extension services, educational and school curriculums should integrate climate change communication, indigenous knowledge and communication media should be used as well as government should be serious with issues of climate change communication so as to cushion the effects of climate change impact in Ogba Egbema Ndoni Local Government Area of Rivers State, Nigeria.

KEYWORDS

climate change; community stakeholders; communication; environment; Nigeria
\end{abstract}

\section{INTRODUCTION}

Globally, communicating the phenomenon of climate change to people especially those in the local communities is a great problem due to the challenges facing communication media, 
information actors and the receiving community stakeholders. Thus, the effects of climate change have become a very import concept which should be communicated to the local community stakeholders who depend on climate for their farm practice, resource management and general livelihood. Climate change is the significant shift in the determining elements that control the climate of a place (Nwaerema, 2020). These climatic elements are rainfall, temperature, humidity, pressure, sunshine et cetera. This elemental shift of climate has resulted to flooding, drought, disease prevalence, heat stress, loss of economic productivity et cetera (Enete, 2014; Elisha, Sawa \& Ejeh, 2017; Amanchukwu et al., 2015; Dioha \& Emodi, 2018). On the other hand, communication is the conveyance of information, facts, valued discussions and messages, one at a time or jointly carried out by actors to stakeholders. Thus, communication is the conveyance of information in two or more directions to identified parties or stakeholders (Branden, 2012). There are several communication media which climate change can be used and conveyed to the community stakeholders in the form of electronic, social and print media (television, radio, internet, newspapers, magazines, forums, Facebook, WhatsApp et cetera) where climate issues can be reached to the local people (Suleiman, 2018). The concept of communicating climate change is to build environmental consciousness to the stakeholders (Hum, 2019).

Today, there is rising need for people to adapt to climate change. Communities should be informed on climate change challenges as they affect their indigenous natural resources. Due to the financial constraint of managing impact of climate change, government, companies, communities and other institutions must resort to communicating climate change occurrence to the people. Climate change communication should inform and educate the stakeholders, do social engagement, bring about changes in social norms and cultural values of the people which should trickle down and sensitize the local people (Moser, 2010; Graham, 2004). The information should communicate the immediate impact and urgent risks of climate change by identifying the best media techniques to reach the people on climate change matters. The communication should contain clear message of the subject matter with futuristic goal to drastically reduce climate change impact Center for Research on Environmental Decisions (CRED) 2009; Department for Communities and Local Government (DCLG) (2007).

Man-made sources in the form of release of poisonous gases, deforestation and other dangerous practices have resulted to a widespread climate change implication in Nigeria (Nwaerema \& Jiya, 2020). Communicating climate change is pertinent in Nigeria local communities because over 70 percent of the population depend on agriculture and 80 percent depend on rainfall for farm practice as well as fishing (Onwutuebe, 2019; Abdulkadir, Lawal \& Muhammad, 2017; Shiru, Shamsuddin, Noraliani \& Eun-Sung, 2018; Ebele \& Emodi, 2016; Ministry of Environment, 2014). Communicating climate change will reduce its effects on rural fisheries, food security, health, forestry, economy, transportation and energy consumption (Idowu et al., 2011; Ogbuabor \& Egwuchukwu, 2017; Nkechi, Onah, Ali \& Eze, 2016; Ebele \& Emodi, 2016).

The problems of communicating climate change to the people has a global dimension. Boussalis, Travis \& Mirya (2018) stated in a study conducted in 82 large cities of USA found that vulnerability of cities to climate change is associated with the level of communication. Thus, expert reports showed that local level adaption and mitigation can be influenced by the degree in which climate change issues are communicated in the USA. Furthermore, some studies have tracked newspaper coverage of climate change communication to the stakeholders in various parts of the world. In Russia, Boussalis et al. (2016) identified 11,131 climate-related articles from 65 papers within 35-year interval. Boykoff (2015) established that failure in global climate change communication is influenced by the denial of people to know the reality of climate change in the form of negative effects, human factors 
and the overall failure of climate change communicators based on the available media of information.

The problem of climate change communication has lingered over the years and has become a contemporary issue faced by man and his environment especially those living in the rural communities. The media of climate change communication in Nigeria are still weak and the channels to reach people at the grassroots are a top priority to effectively reach-out the stakeholders. The study area is prone to severe impacts of climate change due to the exploration and exploitation of multinational oil and gas companies as well as their subsidiaries, hence, calls for investigation of climate change occurrence and their levels of communication to the vulnerable community stakeholders. Studies have shown the importance of communicating climate change occurrence and its impacts on the lives of people, therefore, this research objectively examined climate change communication in Ogba Egbema Ndoni LGA of Rivers State as it occurred in the local community environment and establish the most effective media of communicating climate change phenomenon to the stakeholders.

\section{RESEARCH METHODS}

Ogba Egbema Ndoni Local Government Area is located within latitude 506'0.000 to $5042^{\prime} 0.000$ and longitude $6018^{\prime} 0.000$ to 703 ' 0.000 (figure 1). The study area is one of the Local Government Areas (LGA) of Rivers State in Nigeria, in the Niger Delta area, along the corridors of the Atlantic Ocean. The LGA has current projected population of 445,760 persons National Population Commission (NPC), 2006). The LGA hosts different multinational oil companies of Shell Production and Development Company of Nigeria (SPDC), Nigeria Agip Oil Company (NAOC) and Total E and P Nigeria Limited (TEPNG) respectively. These companies and their subsidiaries exploit and explore the oil and gas resources of the area with severe impact on the climate pattern of the area. Thus, the major occupation of the people is basically subsistence farming and general trading. Ogba Egbema Ndoni LGA is characterised with the climatic condition of Port Harcourt area in the Niger Delta region of Nigeria influenced by the north-easterly winds within the Inter-Tropical Convergence Zone (ITCZ) resulting to the harmattan season. Rainfall is between $2000 \mathrm{~mm}$ to $2500 \mathrm{~mm}$ with highest values from April till October of every year. The study area experience intense temperature of above 320C from January to March and as low as 260C within July period. It has annual humidity of $85 \%$, cloud cover of 6 oktas, wind speed of 0 $3 \mathrm{~m} / \mathrm{s}$ indicating it is characterized by tropical climate environment (Chiadikobi, Omoboriowo, Chiaghanam, Opatola \& Oyebanji, 2011; Nwaerema \& Edokpa, 2019; Nwaerema \& Nwagbara, 2018).

This study adopted multi-stage cluster sampling approach using questionnaires and participatory interview. The Local Government Area (LGA) is made up of different indigenous clans of Egi, Igburu, Usomini, Ndoni and Egbema respectively forming clusters of stakeholders. Five (5) communities were randomly selected from the five (5) indigenous clans. Sixteen (16) households were randomly sampled in each community bringing the total respondents to four hundred (400). The Taro Yamane (1973) formula $n=N / 1+N(e) 2$ at $95 \%$ confidence level was used to determine the sample size; where $\mathrm{n}=$ sample size, $\mathrm{N}=$ number of people in the population and $\mathrm{E}=$ allowable error (\%) resulting to 400 questionnaires. The survey was randomly selected among farmers, traders and workers above 18 years of age from different households of both male and female gender. The field work was carried out in six (6) months from June to November, 2019. The survey was guided by indigenes who communicated with the respondents using their local languages. After the pilot survey, the questionnaires were developed having four (4) sections on the concept of 
climate change, climate change communication, institutions and agents of climate change communication as well as the interaction of climate change phenomenon and communication strategies. The reliability of instrument used was ascertained using Cronbach's coefficient alpha reliability values to assess the degree to which the variables that make up the scales were able to measure and identify the attributes. The minimum reliability value of 0.60 is recommended for acceptability in a magnitude of one (Nunnally \& Bernstein, 1994). The Statistical Package for Social Sciences (SPSS) was used for the analysis of data. Thus, tables and graphical charts were used to represent the results and findings. The Chi-square statistical test was used to validate the hypothesis that climate change occurrence is not statistically significantly communicated to the stakeholders in the study area.

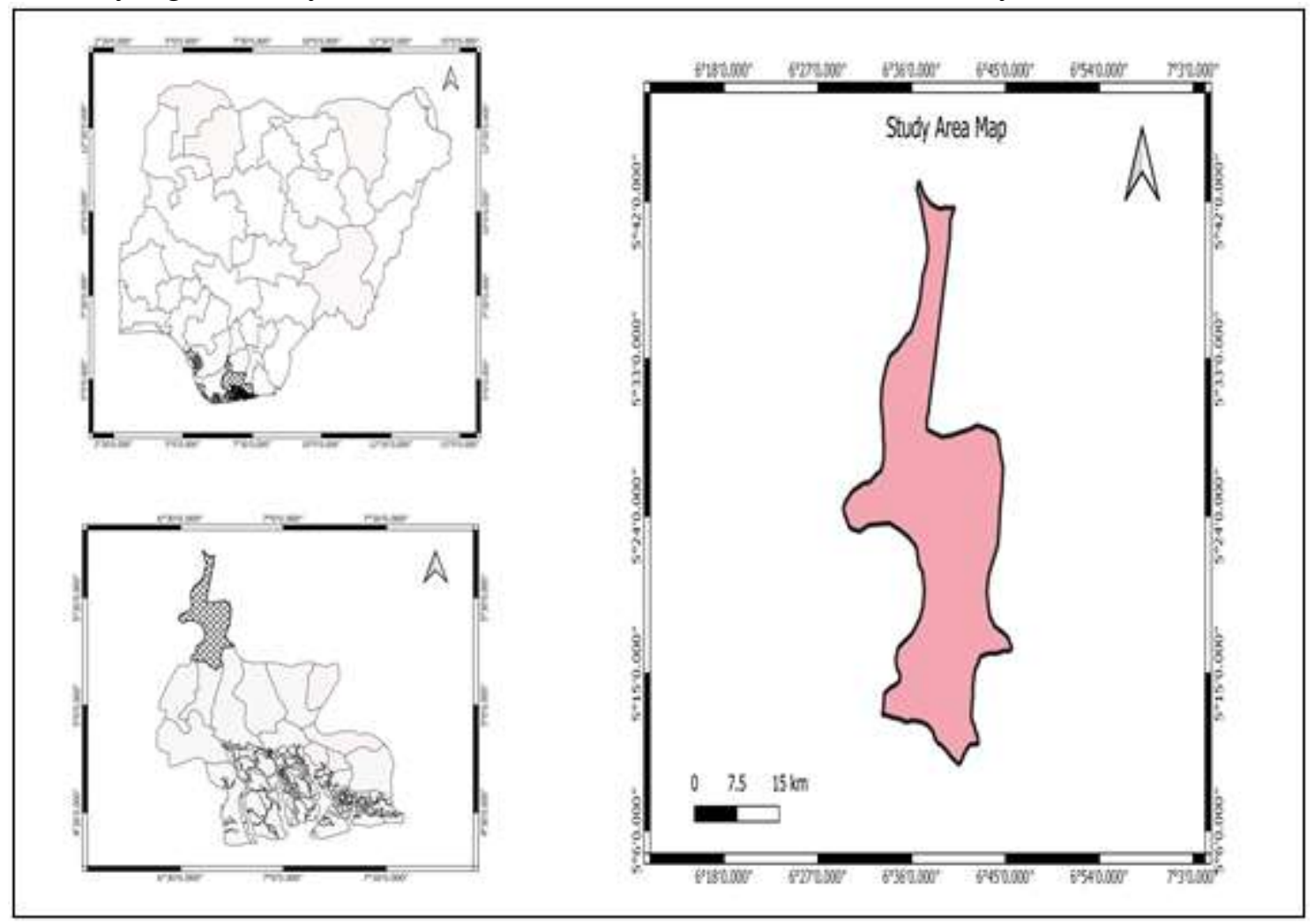

Figure 1. Ogba Egbema Ndoni Local Government Area (ONELGA) in Rivers State, Nigeria

\section{RESULTS AND DISCUSSION}

\section{Survey Response}

The result of the survey showed that $100 \%$ of the questionnaires were recovered. This was possible by the pre-survey conducted which the field assistants were acquainted with the study area and some contacts established with the stakeholders before the actual survey. This suggests that all the respondents were aware of issues of climate change in the communities, objective analysis was carried out and dependable results as well as findings were discussed. The questionnaire was validated with the respondents interview to further establish the dependability of the result and findings of the survey. Also, the Cronbach's coefficient alpha reliability value was greater than 0.6 indicating the reliability of the survey questionnaire using the Linkert scale. 


\section{Stakeholders' Perception of Climate Change}

The respondents were able to establish their agreement with statement of climate change perception (questions 1-4 responses of Table 1). The analysis showed that stakeholders (58.8\% agreed and 38.8\% strongly agreed) knew that climate change was a total shift of the variables of rainfall, temperature, humidity, wind pattern, cloud cover et cetera in their study area. They were aware that man was the real cause of climate change (35.8\% agreed and $58.3 \%$ strongly agreed); climate change had really impacted the stakeholder's way of doing things (35.3\% agreed and 38\% strongly agreed) and that the stakeholders had not adequately adapted to climate change phenomenon with the response rate of $(50.3 \%$ disagree and $19 \%$ strongly disagree) indicating that stakeholders had poor preparedness to hazards of climate change.

Table 1. Stakeholders' Perception of Climate Change $(n=400)$

\begin{tabular}{|c|c|c|c|c|c|c|}
\hline Question & Response & 1 & 2 & 3 & 4 & 5 \\
\hline \multirow[t]{2}{*}{1} & $\begin{array}{l}\text { Climate change is a total shift of the general climatic } \\
\text { condition (rainfall, temperature, humidity, wind } \\
\text { pattern, cloud cover et cetera) }\end{array}$ & 2 & 7 & 1 & 235 & 155 \\
\hline & Percentage $(\%)$ & 0.5 & 1.75 & 0.25 & 58.75 & 38.75 \\
\hline \multirow[t]{2}{*}{2} & $\begin{array}{l}\text { Human is the real cause of climate change (gas } \\
\text { emission, deforestation, blocking of drainage } \\
\text { systems et cetera) }\end{array}$ & 2 & 20 & 2 & 143 & 233 \\
\hline & Percentage $(\%)$ & 0.5 & 5 & 0.25 & 35.75 & 58.25 \\
\hline \multirow[t]{2}{*}{3} & $\begin{array}{l}\text { Climate change has really impacted the stakeholder's } \\
\text { way of doing things (farming, building, clothing, } \\
\text { work and lifestyle et cetera) }\end{array}$ & 62 & 36 & 9 & 141 & 152 \\
\hline & Percentage $(\%)$ & 15. & 9 & 2.25 & 35.25 & 38 \\
\hline \multirow[t]{2}{*}{4} & $\begin{array}{l}\text { The stakeholders have adequately adapted to climate } \\
\text { change phenomenon (early warning system, disaster } \\
\text { preparedness et cetera) }\end{array}$ & 201 & 76 & 11 & 54 & 58 \\
\hline & Percentage $(\%)$ & 50.25 & 19 & 2.75 & 13.5 & 14.5 \\
\hline
\end{tabular}

NB: Strongly agree (5), Agree (4), Neither agree nor disagree (3), Disagree (2) Strongly disagree (1).

\section{Communication of Climate Change to Stakeholders}

The stakeholders noted the extent they were communicated issues on climate change (questions 5-10 responses of Table 2). The respondents (48.3\% disagree and 46.8 strongly disagree) showing that the indigenous local town-crying medium of communication was not adequately used to communicate climate change issues. The respondents (38\% agree and $49.3 \%$ strongly agree) concluded that the radio was adequately used to communicate climate change. They $(35.3 \%$ agree and $46.3 \%$ strongly agree) showed that the Television was adequately used to communicate climate change. The print media were not adequately used to communicate climate change issues ( 24.8 strongly disagree and 25.5 disagree). The social media (WhatsApp, Facebook, Twitter, Instagram, Telegram et cetera) were not adequately used to communicate climate change ( $45.3 \%$ strongly disagree and $44.3 \%$ disagree) showing the least medium of communicating climate change occurrence in the LGA. The town hall meeting was adequately used to communicate climate change $(55.3 \%$ agree and $37.5 \%$ strongly agree) showing the intensity of using community gathering in communicating climate change occurrence to the community stakeholders.

Table 2. Communication of Climate Change to Stakeholders $(n=400)$

\begin{tabular}{|c|l|c|c|c|c|c|}
\hline Question & \multicolumn{1}{|c|}{ Response } & 1 & 2 & 3 & 4 & 5 \\
\hline 5 & $\begin{array}{l}\text { The local town-crying has been adequately used to } \\
\text { communicate climate change }\end{array}$ & 193 & 187 & 5 & 9 & 6 \\
\hline 6 & $\begin{array}{l}\text { Percentage (\%) } \\
\text { che radio has been adequately used to communicate } \\
\text { climate change }\end{array}$ & 48.25 & 46.75 & 1.25 & 2.25 & 1.5 \\
\hline
\end{tabular}




\begin{tabular}{|c|l|c|c|c|c|c|}
\hline & Percentage (\%) & 4.25 & 7.75 & 0.75 & 38 & 49.25 \\
\hline 7 & $\begin{array}{l}\text { The Television has been adequately used to } \\
\text { lommunicate climate change }\end{array}$ & 33 & 39 & 2 & 141 & 185 \\
\hline & Percentage (\%) & 8.25 & 9.75 & 0.5 & 35.25 & 46.25 \\
\hline 8 & $\begin{array}{l}\text { The print media (news papers, magazines, journals, } \\
\text { bulletins et cetera) have been adequately used to } \\
\text { lommunicate climate change }\end{array}$ & 99 & 102 & 1 & 101 & 97 \\
\hline & Percentage (\%) & 24.75 & 25.5 & 0.25 & 25.25 & 24.25 \\
\hline 9 & $\begin{array}{l}\text { The social media (WhatsApp, Facebook, Twitter, } \\
\text { Instagram, Telegram et cetera) have been adequately } \\
\text { used to communicate climate change }\end{array}$ & 181 & 177 & 3 & 17 & 22 \\
\hline & Percentage (\%) & 45.25 & 44.25 & 0.75 & 4.25 & 5.5 \\
\hline 10 & $\begin{array}{l}\text { Town hall meeting have been adequately used to } \\
\text { communicate climate change }\end{array}$ & 221 & 150 & 2 & 16 & 11 \\
\hline & Percentage (\%) & 55.25 & 37.5 & 0.5 & 4 & 2.75 \\
\hline
\end{tabular}

NB: Strongly agree (5), Agree (4), Neither agree nor disagree (3), Disagree (2) Strongly disagree (1).

\section{Institutions and Agents of Communicating Climate Change}

The respondents were able to establish their agreement with statement of the institutions and agents used to communicate climate change (questions 11-13 responses of Table 3). The respondents (37\% disagree and $31 \%$ strongly disagree) that the government was not concerned with climate change communication to the stakeholders showing the level of negligence of government reaching out the local people in communicating climate change. The respondents $(27.8 \%$ agree and $26.3 \%$ strongly disagree) that the host community companies (Agip, Shell SPDC, Total E and P Nigeria Ltd) were concerned with climate change communication to the local community stakeholders. Also, the respondents $(36 \%$ agree and $34.3 \%$ strongly disagree) showed that the Non-government Organizations (NGOs) and Community Based organizations (CBOs) were more concerned with climate change communication to them.

Table 3. Institutions and Agents of Communicating Climate Change

\begin{tabular}{|c|l|c|c|c|c|c|}
\hline Question & \multicolumn{1}{|c|}{ Response } & 1 & 2 & 3 & 4 & 5 \\
\hline 11 & $\begin{array}{l}\text { The government is concerned with climate change } \\
\text { communication }\end{array}$ & 148 & 124 & 8 & 63 & 57 \\
\hline & Percentage (\%) & 37 & 31 & 2 & 15.75 & 14.25 \\
\hline 12 & $\begin{array}{l}\text { The host community companies are concerned with } \\
\text { climate change communication }\end{array}$ & 80 & 95 & 9 & 111 & 105 \\
\hline 13 & Percentage (\%) & 20 & 23.75 & 2.25 & 27.75 & 26.25 \\
\hline & $\begin{array}{l}\text { The non-government organizations (NGOs) and } \\
\text { Community Based organizations (CBOs) are } \\
\text { concerned with climate change communication }\end{array}$ & 49 & 60 & 10 & 144 & 137 \\
\hline & Percentage (\%) & 12.25 & 15 & 2.5 & 36 & 34.25 \\
\hline
\end{tabular}

NB: Strongly agree (5), Agree (4), Neither agree nor disagree (3), Disagree (2) Strongly disagree (1).

\section{Relationship of Climate Change Occurrence and Communication to Stakeholderse}

The respondents established the relationship between climate change occurrence and media communication (questions 14 and 15 responses of Table 4). In this relationship, the respondents (41.8\% agree and $44.5 \%$ strongly agree) actually viewed that climate change occurrence significantly occurs in this area. Also, the respondents (47\% agree and 39\% strongly agree) that climate change communication was adequately carried out in the study area. In order to establish the statistically significant relationship between climate change occurrence and communication to stakeholders (questions 14 and 15), the Chi-square test showed table value of 9.49 and calculated value of 4.6206 indicating that the calculated value was lesser than the table value. This showed that climate change occurrence was not 
statistically significantly communicated to the community stakeholders in Ogba Egbema Ndoni LGA of Rivers State, Nigeria

Table 4. The Relationship of Climate Change Occurrence and media Communication to Stakeholders

\begin{tabular}{|c|l|c|c|c|c|c|}
\hline Question & Response & 1 & 2 & 3 & 4 & 5 \\
\hline 14 & $\begin{array}{l}\text { Climate change phenomenon significantly occurs in } \\
\text { this area }\end{array}$ & 23 & 27 & 5 & 167 & 178 \\
\hline & Percentage (\%) & 5.75 & 6.75 & 1.25 & 41.75 & 44.5 \\
\hline 15 & $\begin{array}{l}\text { Climate change communication is adequately carried } \\
\text { out in this area }\end{array}$ & 20 & 33 & 3 & 188 & 156 \\
\hline & Percentage (\%) & 5 & 8.25 & 0.75 & 47 & 39 \\
\hline
\end{tabular}

\section{Discussion}

The respondents in Ogba Egbema Ndoni LGA were aware that climate change is real and human caused climate change occurrence. They also knew that their way of life had been influenced by climate change, but they had not adapted to climate change disaster. The opinion of the respondents is in tandem with the view of Roser-Renouf \& Maibach (2010) who established that the Americans believed that climate change occurrence is real and that 40 percent of Americans agree that climate change had its negative consequences with limited adaptation strategies by the people. Furthermore, Center for Research on Environmental Decisions (CRED) in the Psychology of Climate Change Communication (2009) concluded that the threat of climate change would make stakeholders to perceive climate change issues as a critical matter and would like to avoid future impact as well as make behavioral changes (adaptation) and implement necessary actions. However, radio, television and town-hall meeting and relatively print media were the most effective media of communicating climate change. This is because of the availability of relatively stable electricity and accessibility to electronic media common in the area. According to the field interviews carried out, the multinational oil companies have supported community electricity generation and supply to host communities thereby enabling them to have regular information on climate change discussions. Furthermore, many town hall-meetings have been held by organizations on climate change education resulting from oil and gas exploration and exploitation in the area. Accordingly, Nwanne (2016) noted that electricity power has greater effects in communicating information to the stakeholders such as the use of radio and television which do not required rigorous and complex intellectual demand to access information. It is a known fact, that access to internet and other social media platforms are challenging to climate change information due to the difficulty in requisite skills to access social media devices which can ultimately inhibit level of education of users. In this vein, social media use in climate change communication is supposedly limited in the study area due to existing high illiteracy level and technicality in the use of electronic devices such as the phones, computers and tablets.

The communication of climate change by institutions showed that the government has weak approach to reaching out local community stakeholders in driving climate change issues. Non-Governmental organizations (NGOs) were able to effectively communicate climate change issues to the community stakeholders. This was followed by the host community companies who were committed to communicating the occurrence of climate change. Sometimes, the NGOs served as consultants to the multinational oil and gas companies who were hired to gather the host community stakeholders at the town halls and inform them the issues of climate change as they affect their way of life and livelihood. Sayne (2011) reported that media communication and sensitization in Nigeria was weak which had resulted to several conflicts across the states and communities. Thus, nonstate 
actors such as NGOs, private practitioners and companies had not been properly used by the government to drive climate change communicate in the country. On the other hand, the media by means of journalism should be able to persuade the government to develop communication policies for effective climate change communication for environmental and national growth (Anaeto \& Anaeto, 2010; Suleiman, 2018). Ifeanyi-obi \& Nnadi (2014) stated that efforts by government of Nigeria and other state actors in communicating climate change was inadequate. Therefore, the weakness of the government in driving climate change communication was observed by the stakeholders and literature had reported the delimitation of state actors in media communication especially in climate change occurrence as it affects the Nigerian people. The result of this survey showed that climate change occurrence has not been adequately communicated in Ogba Egbema Ndoni Local government Area of Rivers State. This indicates that more effort is needed in communicating climate change issues in the area.

\section{CONCLUSION}

This survey established the characterization in the communication of climate change occurrence: implication for environmental sustainability in Ogba, Egbema, Ndoni Local Government Area of River State, Nigeria. Although, there is limited literature on climate change communication in Nigeria. However, many stakeholders have not been adequately communicated on the hazards of climate change resulting to low response in climate change adaptation not withstanding that the greater number of people engage in farming for their livelihood. The perception of climate change in the LGA in terms of climate change concept, their general way of doing things, causes of climate change and coping strategies shows that climate change effect is real to the stakeholders but with low level of readiness to combat the impact of climate change due to poor communication media strategy. However, the indigenous local town-crying communication medium has been poorly used in their climate change information exchanges. The print media and internet social media have not been properly utilized in climate change communication, suspected to be caused by high level of illiteracy. But radio and television have been the advance form of media communication to the stakeholders on climate change matters. The efforts of NGOs, CBOs and host companies in climate change communication have been noticeable in climate change communication to the community people due to their efficiency and simplicity to operate, supported by the relatively stable power supply in the LGA. The government efforts in communicating climate change is very weak due to poor policy development and implementation in the country. However, lack of information on climate change will reduce farm productivity, economic losses, health hazards, educational interaction and general environmental degradation. Therefore, information awareness on climate change should be improved, access to weather information should be enhanced, agricultural extension services should reach the local people as part of coping strategies, educational and school curriculums should integrate climate change communication, indigenous knowledge and communication media should be involved, institutions and the government should propagate climate change communication up to the local and rural areas to enable the stakeholders be properly acquainted in climate change occurrence for the purpose of amelioration or total cushioning of the hazards associated with climate change occurrence. 


\section{REFERENCES}

Abdulkadir, A. Lawal, A.M. \& Muhammad T. I. (2017). Climate change and its implications on human existence in Nigeria: a review. Bayero Journal of Pure and Applied Sciences, 10(2), 152-158. Retrieved from https://www.ajol.info/index.php/bajopas/article/ viewFile/170772/160195

Amanchukwu, R. N. (2015). Climate change education in Nigeria: The role of curriculum review. Education, 5(3): 71-79. doi:10.5923/j.edu.20150503.01.

Anaeto, S. G. \& Anaeto, M. (2010). Development communication: principles and practice. Ibadan: Stirling-Horden Publishers Ltd.

Anaman, K. \& Okai, J. (2016). Extent of Awareness of Birth Control Methods and Their Use by Women in a Peri-Urban Area of Accra, Ghana. Modern Economy, 7, 39-54. doi:10.4236/me.2016.71005.

Boussalis, C., Coan, T. G. \& Poberezhskaya, M. (2016). Measuring and modeling Russian newspaper coverage of climate change. Global Environmental Change, 41, 99-110. Retried from http://irep.ntu.ac.uk/id/eprint/28934/.

Boykoff, M., Daly, M., Gifford, L., Luedecke, G., McAl-lister, L., Nacu-Schmidt, A. \& Andrews, K. (2015). World newspaper coverage of climate change or global warming, 2004-2015. Center for Science and Technology Policy Research, Cooperative Institute for Research in Environ-Mental Sciences, University of Colorado.

Branden, B. J. (2012). Climate Change Communication: A Provocative Inquiry into Motives, Meanings, and Means. Risk Analysis, 32(6), 973-991. doi:10.1111/j.15396924.2011.01731.x.

Center for Research on Environmental Decisions [CRED] (2009). The Psychology of Climate Change Communication. A Guide for Scientists, Journalists, Educators, Political Aides, and the Interested Public. New York. Retrieved from http://guide.cred.columbia.edu/.

Chiadikobi, K. C., Omoboriowo, A. O., Chiaghanam, O. I., Opatola, A. O., \& Oyebanji, O. (2011). Flood Risk Assessment of Port Harcourt, Rivers State, Nigeria. Advances in Applied Science Research, 2(6), 287-298. Retrieved from www.pelagiaresearchlibrary.com.

Boussalis, C., Travis G. C. \& Mirya, R. H. (2018). Climate Change Communication from Cities in the United States. Climatic Change 149(2), 1-1. doi:10.1007/s10584-018-2223-1.

Department for Communities and Local Government [DCLG] (2007). Climate change communication strategy: A West Sussex Case Study http://www.espaceproject.org/part1/publications/reading/WSCCClimateCommunication s\%20Strategy.pdf.

Dioha, M. O. \& Emodi, N. V. (2018). Energy-climate dilemma in Nigeria: Options for the future. IAEE Energy Forum.https://www.google.com/url?sa=t\&rct=j\&q=\&esrc=s\&source=web\&cd=108\&ve $\mathrm{d}=2$ ahUKEwihv4iA27kAhVoc98KHWNKDtw4MhAWMDl6BAgQEAI\&url=https\%3 A $\% 2 \mathrm{~F} \% 2 \mathrm{Fwww}$.iaee.org\%2Fen\%2Fpublications\%2Fnewsletterdl.aspx \%3Fid\%3D465 \&usg=AOvVaw3qHlxFJnRFCXox9HBg4d-I.

Ebele, N. E. \& Emodi, N. V. (2016). Climate change and its impact in Nigerian economy. Journal of Scientific Research \& Reports, 10(6), 1-13. Retrieved from http://www.journaljsrr.com/index.php/JSRR/article/view/21917/40737.

Elisha, I., Sawa, B. A. \& Ejeh, U. L. (2017). Evidence of climate change and adaptation strategies among grain farmers in Sokoto State, Nigeria. IOSR Journal of Environmental Science, Toxicology and Food Technology, 11(3), 1-7. Retrieved from http://www.iosrjournals.org/iosr-jestft/papers/vol11-issue\%203/Version-2/A1103020107.pdf. 
Enete, I. C. (2014). Impacts of climate change on agricultural production in Enugu State, Nigeria. Journal of Earth Science \& Climatic Change, 5(9), 234. Retrieved from https://www.omicsonline.org/openaccess/impacts-of-climate-change-on-agriculturalproduction-in-enugu-state-nigeria-2157-7617.1000234.php?aid=32633.

Federal Ministry of Environment (2014). United Nations Climate Change Nigeria. National $\begin{array}{llllll}\text { Communication } & \text { (NC). } & \text { NC } & 2014 . & \text { Retrieved from }\end{array}$ https://unfccc.int/sites/default/files/resource/nganc2.pdf.

Graham, A. C. (2004). A Social Communication Perspective Toward Public Participation: The Case of the Cispus Adaptive Management Area. In Communication and Public Participation in Environmental Decision Making. 55 Eds. Depoe, Stephen P., John W. Delicath, and Marie-France Aepli Elsenbeer. Albany, NY: State University of New York Press.

Haider, H. (2019). Climate change in Nigeria: Impacts and responses. K4D Helpdesk Report 675. Brighton, UK: Institute of Development Studies.

Ifeanyi-obi, C.C. \& Nnadi, F.N. (2014). Climate change adaptation measures used by farmers in South-South Nigeria. Journal of Environmental Science, Toxicology and Food Technology, 8(4), 1-6. doi:10.9790/2402-08410106.

Moser, S. (2010). Communicating climate change: history, challenges, process, and future directions. WIRES Climate Change Volume 1, January/February 2010. John H. Wiley and Sons, Ltd.

National Population Commission [NPC]. (2006). Report for National Planning. Nigeria: Author. Retrieved from: https://www.citypopulation.de/php/nigeriaadmin.php?adm1id=NGA033.

Nkechi, O. Onah, N., Ali, A. \& Eze, E. (2016). Mitigating climate change in Nigeria: African traditional religious values in focus. Mediterranean Journal of Social Sciences, 7(6), 299308. Retrieved from https://www.mcser.org/journal/index.php/mjss/article/view/9612.

Nunnally, J. C. \& Berstein, I. H. (1994). Psychometric Theory. 3rd ed, New York: McGrawHill.

Nwaerema, P., \& Nwagbara, M. O. (2018). Spatial and Temporal Variability of Weekday Urban Heat Island in Port Harcourt Metropolis and Environs. The International Journal of Science and Technoledge, 6(3), 127-136. wwww.theijst.com.

Nwaerema, P., \& Edokpa, D. (2019). Regional Assessment of Population and Warming of a Tropical Country, Nigeria, from 2006 to 2036. Environmental and Earth Sciences Research Journal, 6(1), 1-25. doi.org/10.18280/eesrj.060101.

Nwaerema, P. (2020). Impact of Climate Change on Insects, Pest, Diseases and Animal Biodiversity. International Journal of Environmental Science and Natural Resources, 23(5), 556123. doi:10.19080/IJESNR.2020.23.556123.

Nwaerema, P. \& Jia, S. N. (2020). Evaluation of Temperature and Urban Heat Island Variability in Days of the Week and Weekends. International Journal of Human Capital in Urban Management. http://www.ijhcum.net/article_44693.html.

Nwanne, B. U. (2016). Journalism and New Media in Nigeria: Issues, Challenges and Prospects. International Journal of Academic Research and Reflection, 4(3), 86-92. Retrieved from http://www.idpublications.org/international-journals-of-academicresearch-and-reflection/.

Ogbuabor, J. E. \& Egwuchukwu, E. I. (2017). The impact of climate change on the Nigerian economy. International Journal of Energy Economics and Policy, 7(2), 217-223. Retrieved from https://dergipark.org.tr/en/download/article-file/361739.

Onwutuebe, C. J. (2019). Patriarchy and Women Vulnerability to Adverse Climate Change in Nigeria. doi.org/10.1177/2158244019825914SAGE. 
Roser-Renouf, C. \& Maibach, E. (2010). Communicating Climate Change-Draft. The Encyclopedia of Technology Communication. Sage Publications.

Sayne, A. (2011). Climate Change Adaptation and Conflict in Nigeria. Special Report, United States Institute of Peace. Retrieved from http://www.usip.org/.

Shiru, M. S., Shamsuddin S., Noraliani, A. \& Eun-Sung, C. (2018). Trend Analysis of Droughts During Crop Growing Seasons of Nigeria. Sustainability, 10(3), 871. doi:/10.3390/su10030871.

Suleiman, J. (2018). The Media, Implementation of the Nigerian National Communication Policy, and Citizens Participation in Development. European Scientific Journal, 4(2), 193-215. doi:10.19044/esj. 2018.v14n26p193.

Yamane, T. (1973). Statistics: An Introductory Analysis. 3rd Edition, Harper and Row, New York. 